KRONIKA

STUDIA NORWIDIANA 37:2019

DOI: http://dx.doi.org/10.18290/sn.2019.37-17

\title{
ROLF FIEGUTH
}

\section{CHRZEŚCIJAŃSTWO DLA WSZYSTKICH. PARE SŁÓW NT. QUIDAMA C. NORWIDA ${ }^{1}$}

Wielce Szanowni Państwo, Drodzy Przyjaciele,

Chciałbym najserdeczniej podziękować Fundacji Norwidowskiej za zaszczytne wyróżnienie, drogiej Mirosławie Hanusiewicz-Lavallee za wzruszającą laudację i obecnym kolegom norwidoznawcom za długoletnią solidarność z moją osobą.

Dziękuję też bardzo za możliwość powiedzenia w tym miejscu paru słów na temat mojej propozycji odczytania poematu Quidam, opartej na mojej książce Zaproszenie do Quidama ${ }^{2}$. Jest ona nie we wszystkim nowa, ale też nie we wszystkim konwencjonalna.

Zacznę od kilku twierdzeń na temat norwidowskiego traktowania czasu i o swoiście syntetycznym charakterze wielu momentów opowiadanych w Quidamie. Norwid uważał pojawienie się Chrystusa na ziemi za punkt wyjścia cichej, powolnie postępującej rewolucji, która nosi ze sobą długą prehistorię w postaci kultury greckiej i judaizmu, trudną aktualność wielokulturowej cywilizacji rzymskiej czasów imperatora Adriana i daleką perspektywę przyszłości sięgającej (nie tylko) do XIX w. Konkretnie w poemacie prowadzi wzgląd na tę cichą, powolną rewolucję do przepastnych efektów luster w lustrze. Rzym odbija się sam w sobie domyślnie we wszystkich fazach swej historii, ale też w nowych Rzymach, takich jak Petersburg, Londyn czy Paryż. Analogiczne zjawisko da się dostrzec $\mathrm{w}$ każdym $\mathrm{z}$ pierwszoplanowych bohaterów poematu. Ograniczę się tu do jednego tylko przykładu: W greckim filozofie Artemidorze odbija się w trybie wysoce dyskretnym i aluzyjnym - wiele postaci różnych czasów, w tym

\footnotetext{
${ }^{1} \mathrm{Z}$ lekka przeredagowany tekst przemówienia laureata „Medalu za rozpowszechnienie wiedzy o Cyprianie Norwidzie" na KUL-u 16 X 2017 r.

${ }^{2}$ R. FIEGUTH, Zaproszenie do "Quidama”. Portret poematu C. Norwida, Kraków 2014.
} 
$\mathrm{z}$ jednej strony Platon, ale też Seneka, a z drugiej strony, prawie eksplicytnie, jakikolwiek modny filozof czynny nad XIX-wieczną Sekwaną - oraz, tak mi się wydaje, Zygmunt Krasiński, i chyba po trosze też August Cieszkowski. Podobne efekty są aluzyjnie obecne we wszystkich innych głównych i wielu pobocznych postaciach Quidama.

Nie brak też całych epizodów, które również wywierają efekt luster w lustrze. Jako najważniejszy z nich narzuca się powstanie żydowskie, w którym odbijają się wszelkie wcześniejsze powstania antyczne, nieżydowskie i żydowskie, ale też nowożytne europejskie, w tym przede wszystkim polskie. Wspomniany efekt wiąże się ze specjalnym traktowaniem czasu w Quidamie. Konkuruje tu bowiem tradycyjna koncepcja chronologicznego mijania czasu - z zasadą wieczności, czyli ponadczasowej jednoczesności tego, co nazywamy przeszłością, teraźniejszością i przyszłością. Współistnienie tych dwu koncepcji doprowadza do tego, że wiele momentów opowiadanych w poemacie ma charakter syntetyczny nawet w granicach kalendarza opowiadanego. Akcja poematu rozwija się zarówno w dwu niby nieprzerwanych ciągach kilku dni, może po trzech czy czterech dniach, które dzieli nieokreślony dłuższy okres od wyjazdu Barchoba do Palestyny aż do pojawienia się u Jazona wysłańca od powstania żydowskiego. Ale jakiś element dłuższego trwania wkracza też do każdego z dwu ciągów dni, jest w nich ,przemilczany”, a więc w nich zawarty. Przykładem jest scena seansu filozoficznego w domu Artemidora, która stanowi zarówno wydarzenie ,jednorazowe", jak i syntezę wielu przemilczanych podobnych seansów, na których był czy będzie obecny Syn Aleksandra. Podobnie trzy eksplicytne spotkania Syna Aleksandra z Zofią są syntezą znacznie dłuższego i częstszego kontaktu, który nie jest zresztą do końca przemilczany, gdyż informuje nas o nim dziennik bohatera poematu. Syntezę częstych spotkań imperatora Adriana z filozofem Artemidorem stanowi też opis jednego $\mathrm{z}$ nich $\mathrm{w}$ księdze XIX - i podobnie jest $\mathrm{z}$ wieloma innymi epizodami Quidama. Podkreślę, że podobne syntezy czasowe są przede wszystkim zakotwiczone w opowiadanym aktualnym czasie za rządów Adriana; inna rzecz, że pewne opowiadane momenty w dodatku mogą uczestniczyć w szerszych czasowych efektach luster w lustrze, obejmując zarówno epoki poprzedzające erę Adriana, jak i okresy dużo późniejsze. Z tym wszystkim wykazuje utwór cechy skondensowanej noweli wierszowanej, bliskiej czasami dramatu na temat losów grupki bohaterów przebywających w pewnym momencie za rządów Adriana w Rzymie - a jednocześnie ciągle rozrasta się na rzymską „przy-powieść”, czyli na powieść alternatywną, i dalej na miniaturową chrześcijańską epopeję ludzkościową o wielkim zasięgu historycznym i z finezyjnymi aluzjami do sytuacji XIX-wiecznej Europy i Polski. 
W Norwidowskiej wizji procesu wywołanego przez rewolucję chrystusową, a także w narracji Quidama współistnieją ze sobą dwa aspekty: aspekt „łagodnego prawa” i aspekt drastycznych zdarzeń. Termin „łagodnego prawa” (das sanfte Gesetz) zapożyczam tu od Adalberta Stiftera ${ }^{3}$, zachęcony przez Christiana Zehndera. W myśl „łagodnego prawa” działa ów proces w sposób dyskretny, najczęściej na dalekich peryferiach świadomości zbiorowej i indywidualnej, poza jasną wiedzą ludzi i ludzkości, ale niepowstrzymanie jak podwyższenie poziomu wód gruntowych. $Z$ drugiej strony manifestuje się ten sam proces czasem poprzez zdarzenia bardzo drastyczne i brutalne, które w Quidamie sięgają od trzech morderstw nad bohaterami poematu do żydowskiej wojny powstańczej w Palestynie - przy czym związek tych wszystkich zdarzeń z procesem chrystusowym bywa przeróżny. Najdobitniej manifestuje się w Quidamie konflikt między tymi dwoma aspektami w konkurencji między efektami „łagodnego prawa” na reakcje i sumienia indywidualnych bohaterów poematu a wątkiem "mesjanistycznego" powstania żydowskiego i reakcji reżimu Adriana.

Cicha rewolucja chrystusowa wpływa na prywatne reakcje i losy każdej z pierwszoplanowych osób poematu bez ich jawnej wiedzy, przy czym w bardzo różnicowany sposób. Wszyscy lub prawie wszyscy ludzie opisani w Quidamie są w jakiejś mierze świadkami albo nawet kapłanami tej rewolucji, w większości „bezwiednymi i niedojrzałymi“ (zob. wiersz z Vade-mecum-XV. Sfinks). Nie wiedząc o tym czy nawet zaprzeczając temu - noszą z sobą, na sobie czy w sobie w różnym stopniu ślady owej cichej rewolucji.

Symptomy nowej ery chrystusowej w życiu prywatnym widać w wątku miłosnym poematu, który, jak mi się wydaje, nie znalazł odpowiedniego zainteresowania $\mathrm{w}$ dotychczasowych badaniach nad poematem. Mężczyźni i kobiety są tu na samym początku stawania się indywiduami i kochania w „dzisiejszym” sensie, czyli uznając w kochanym człowieku inne Ja, inne indywiduum. Najbardziej tkwi jeszcze w pogańskim trybie nagiego erotyzmu para Luciusa Pomponiusa i Elektry-Diwy. Ale nawet rzymski dandys Lucius ma prawie karykaturalne wyrzuty sumienia w związku ze swą miłością do greckiej hetery i poetessy Zofii. Natomiast samą Elektrę, młodziutką tancerkę cyrkową, coś w pewnym momencie ciągnie aż komicznie do Jazona, przy czym nie zdaje sobie sprawy z tego, że jest to kapłan Boga i Abrahama i Pawła z Tarsu, i że nosi hellenizowaną formę imienia Joszue, czyli Jezus.

\footnotetext{
${ }^{3}$ Adalbert Stifter, wybitny austriacki pisarz (1805-1868). Koncepcję „łagodnego prawa” rządzącego światem niezależnie od inicjatyw człowieka wyłożył w przedmowie do dwutomowego zbioru szkiców w prozie Bunte Steine. Ein Festgeschenk [Kolorowe kamienie. Dar na uroczystość], Pest 1853.
} 
Piękną Zofię też dziwnie ciągnie do tego samego Jazona, od którego spodziewa się leczenia choroby miłości. Ją utrzymuje raczej jeszcze w starszym antycznym duchu jako metresę grecki filozof Artemidor. Natomiast kocha ja miłością w duchu już całkiem chrześcijańskim młody Aleksander z Epiru, poszukiwacz mądrości i prawdy, tudzież poeta - kocha ją niezupełnie bez wzajemności, a jednak nieszczęśliwie, bo bez wzajemności i jedności sumień i dusz. Ale pewne akcenty chrześcijańskie towarzyszą Zofii od początku poematu, chociażby ze względu na bogate aluzje greckie, żydowskie i chrześcijańskie, zawarte w jej imieniu, ale także w postaci jej egipskiej służącej, kobiety po chrześcijańsku cierpliwej i pogodnej i najprawdopodobniej pomyślanej przez Norwida jako niejawna chrześcijanka. Akcent chrześcijański będzie miało też ostatnie spotkanie zdegradowanego ,pielgrzyma” Artemidora z umierającą Zofią, bo oboje zrzucają $\mathrm{z}$ siebie $\mathrm{w}$ tym momencie swoje wcześniejsze egoizmy. Były filozof imperialny, a teraz banita, nie dba już o własną skórę, a uczestniczy wbrew zakazowi pobytu w Rzymie w pogrzebie Zofii; w opcji Norwida już to jest aktem w duchu chrześcijańskim.

Przypomnę na zakończenie krótkiego odczytu, że nie chciałbym pomniejszać roli Syna Aleksandra - to on jest najdobitniejszym przykładem oddziaływania sfery chrystusowej w poemacie. Ale moją tezą jest, że nie tylko on, ale też wszyscy inni bohaterowie utworu są $\mathrm{w}$ tej czy innej mierze objęci tą sferą - w tym zarówno Artemidor i Zofia, jak i szczególnie rabbi Jazon i Barchob. I jeszcze jedno: sfera chrystusowa obejmuje także pewne części ludu rzymskiego, dość bogato charakteryzowanego $\mathrm{w}$ poemacie. $\mathrm{Z}$ ludu wyłania się pierwszy quidam, ogrodnik, który ze swymi towarzyszami staje przed rzymskim sądem publicznym, ale też drugi quidam, który wygłasza kazanie nad trupem Syna Aleksandra. W sumie można skonstatować, że w Quidamie z wyjątkiem rzymskich praktyk religijnych każda inna kultura, filozofia i religia obecna w stolicy imperatora Adriana jest traktowana $\mathrm{z}$ wybitnym respektem, ale $\mathrm{z}$ bardzo dyskretnie zarysowaną perspektywą przyszłego ujścia ich wszystkich w szeroko rozumianym chrześcijaństwie. 